DOI: $\square$ https://doi.org/10.15407/techned2020.05.010

\title{
MULTIOBJECTIVE SYNTHESIS OF TWO DEGREE OF FREEDOM NONLINEAR ROBUST CONTROL BY DISCRETE CONTINUOUS PLANT
}

Journal

Publisher

ISSN

Issue

Pages
Tekhnichna elektrodynamika

Institute of Electrodynamics National Academy of Science of Ukraine 1607-7970 (print), 2218-1903 (online)

No 5, 2020 (September/October)

$10-14$

\section{Authors}

B.I. Kuznetsov ${ }^{1 *}$, T.B. Nikitina ${ }^{2 \star *}$, I.V. Bovdui ${ }^{1 \star \star *}$

1 - Institute of Technical Problems of Magnetism National Academy of Sciences of Ukraine, 19, Industrialna st., Kharkiv, 61106, Ukraine, e-mail: kuznetsov.boris.i@gmail.com

2 - Kharkov National Automobile and Highway University,

25, Yaroslava Mudroho st., Kharkiv, 61002, Ukraine

* ORCID ID : https://orcid.org/0000-0002-1100-095X

** ORCID ID : https://orcid.org/0000-0002-9826-1123

*** ORCID ID : https://orcid.org/0000-0003-3508-9781

\section{Abstract}

The method of accuracy improving and uncertain plant parameters sensitivity reducing based on multiobjective synthesis of two degree of freedom nonlinear robust control by

discrete-continuous plant is developed. Synthesis of nonlinear robust regulators and nonlinear robust observers reduces to Hamilton-Jacobi-Isaacs equations solution. The robust control target vector is choiced by multicriterion nonlinear programming problem solution in which the objective function vectors is direct indexes performance vector that are presented to the system in various modes of its operation. The robust control target vector calculated by synthesized nonlinear robust control system modeling for various modes of system operation with different input signals and for various plant parameters values. The dynamic characteristics modeling end experimental researching results of a synthesized nonlinear electromechanical servo system for system operation various modes with different input signals and for plant parameters various values are given. References 8 , figure 1. 
Key words: discrete-continuous plant, nonlinear robust control, dynamic characteristics simulation and experimental researches.

Received: 15.02 .2020

Accepted: 21.04 .2020

Published: 25.08.2020

\section{References}

1. Binroth W. Closed-loop optimization program for the M60A1 tank gun stabilization system. Rock Island Arsenal, 1975. 251 p.

2. Kondratenko I.P., Zhyltsov A.V., Pashchyn N.A., Vasyuk V.V. Selecting induction type electromechanical converter for electrodynamic processing of welds. Tekhnichna elektrodynamika No 5. Pp. 83-88. (Ukr) DOI: https://doi.org/10.15407/techned2017.05.083

3. Mazurenko L.I., Dzhura O.V., Romanenko V.I., Bilyk O.A. Numerical investigation of induction generators with two stator windings in welding complexes with pwm current regulators. Tekhnic hna elektrodynamika

. 2012. No 3. Pp. 83-84. (Ukr)

4. Peresada S., Kovbasa S., Korol S., Zhelinskyi N. Feedback linearizing field-oriented control of induction generator: theory and experiments. Tekhnichna elektrodynamika. 2017. No 2. Pp. 48-56. DOI:

//doi.org/10.15407/techned2017.02.048

https:

5. Mituhiko Araki, Hidefumi Taguchi Two-Degree-of-Freedom PID Controllers. International Journal of Control, Automation and Systems

. 2003. Vol. 1. No 4. Pp. 401-411.

6. William M. McEneaney Max-plus methods for nonlinear control and estimation. Birkhauser Boston Basel Berlin, 2006. 256 p.

7. Wilson J. Rugh Nonlinear system theory the Volterra. The Johns Hopkins University Press, 2002. $330 \mathrm{p}$.

8. Ummels M. Stochastic Multiplayer Games Theory and Algorithms. Amsterdam: Amsterdam University Press, 2010. 237 p. DOI: https://doi.org/10.5117/9789085550402 
$\underline{\text { PDF }}$

@ $\Theta \Theta \Theta$

This work is licensed under a Creative Commons Attribution-NonCommercial-NoDerivatives 4.0 International License 